\title{
Magnesium in the water of Japanese quails kept under comfort zone and under thermal stress
}

\section{Magnésio na água de codornas japonesas mantidas em zona de conforto e sob estresse térmico}

\author{
Valéria Pereira Rodrigues ${ }^{1}$; Dermeval Araújo Furtado ${ }^{2}$; Neila Lidiany Ribeiro3*; \\ Ladyanne Raia Rodrigues ${ }^{1}$; Claudia Goulart Abreu ; Janete Gouveia Souza ${ }^{5}$
}

\section{Highlights}

Japanese quails can consume water with magnesium levels of up to $350 \mathrm{mg} / \mathrm{L}$. Japanese quails can maintained at temperatures of up to $32^{\circ} \mathrm{C}$.

Water with magnesium levels of $350 \mathrm{mg} \mathrm{L}^{-1}$ does not affect quail performance.

\begin{abstract}
The objective was to evaluate the increasing levels of magnesium in the water supplied to laying quails (Coturnix coturnix japonica), kept in climatic chambers under thermoneutral temperature and thermal stress, on their performance and morphometry of their organs. The birds were distributed in a completely randomized design, $2 \times 4$ factorial arrangement, 2 temperatures $\left(24\right.$ and $32^{\circ} \mathrm{C}$ ) and 4 levels of magnesium in the water $\left(50,150,250\right.$ and $\left.350 \mathrm{mg} \mathrm{L}^{-1}\right)$, with six replicates and eight birds per experimental unit. The data were subjected to analysis of variance and the means compared by the Tukey test at $5 \%$ probability level. The magnesium levels in the water did not affect $(P>0.05)$ the production performance and morphometry of the organs, with less water consumption at the magnesium level of $150 \mathrm{mg} \mathrm{L}^{-1}$, and birds kept at $32^{\circ} \mathrm{C}$ had a reduction in feed consumption and feed conversion, but without affecting organ morphometry. Japanese quails in the production phase can consume water with magnesium levels up to $350 \mathrm{mg} \mathrm{L}^{-1}$ without having their production performance and morphometry of organs affected and raised in an environment with temperatures of up to $32^{\circ} \mathrm{C}$.
\end{abstract}

Key words: Ambience. Climate chamber. Quail farming. Coturnix coturnix japonica.

1 Doctors, in Agricultural Engineering, Universidade Federal de Campina Grande, UFCG, Campina Grande, PB, Brazil. E-mail:valeriazootecnia@hotmail.com; ladyannezootecnia@hotmail.com

2 Prof., Head of the Agricultural Engineering Academic Unit, UFCG, Technology and Natural Resources Center, Campina Grande, PB, Brazil. E-mail: araujodermeval@gmail.com

${ }^{3}$ Scholarship PCI/CNPq, Instituto Nacional do Semi-Árido, Campina Grande, PB, Brazil. E-mail: neilalr@hotmail.com

4 Professor at the Universidade Estadual Vale do Acaraú, UVA, Center for Agricultural and Biological Sciences, CCAB, Campus da Betânia, Sobral, CE, Brazil. E-mail: clcgoulart@hotmail.com

5 Professor at the Universidade Federal do Rio Grande do Norte, UFRN, Academic Unit Specialized in Agricultural Sciences, Macaíba, RN, Brazil. E-mail: jnobre5@hotmail.com

* Author for correspondence

Received: July 07, 2021 - Approved: Nov. 16, 2021 


\section{Resumo}

O objetivo foi avaliar os níveis crescentes de magnésio na água fornecida a codornas (Coturnix coturnix japonica) em postura, mantidas em câmaras climáticas sob temperatura termoneutra e estresse térmico, sobre o desempenho e morfometria dos órgãos das aves. As aves foram distribuídas em delineamento inteiramente casualizado, arranjo fatorial $2 \times 4,2$ temperaturas $\left(24\right.$ e $\left.32{ }^{\circ} \mathrm{C}\right)$ e 4 níveis de magnésio na água (50, 150, 250 e $350 \mathrm{mg} \mathrm{L}^{-1}$ ), com seis repetições e oito aves por unidade experimental e os dados submetidos à análise de variância e as médias comparadas pelo teste de Tukey a $5 \%$ de probabilidade. Os níveis de magnésio na água não afetaram $(P>0,05)$ o desempenho produtivo e a morfometria dos órgãos, com menor consumo de água ao nível de $150 \mathrm{mg} \mathrm{L}^{-1}$ de magnésio e, as aves mantidas a $32{ }^{\circ} \mathrm{C}$ tiveram uma redução no consumo de ração e conversão alimentar, mas sem afetar a morfometria dos órgãos. Codornas japonesas em fase de produção podem consumir água com níveis de magnésio de até $350 \mathrm{mg}$ $\mathrm{L}^{-1}$ sem ter o desempenho produtivo e a morfometria dos órgãos afetados e criados em ambiente com temperatura de até $32^{\circ} \mathrm{C}$.

Palavras-chave: Ambiente. Câmara climática. Criação de codornas. Coturnix coturnix japonica.

\section{Introduction}

Quail farming is an expanding activity in semi-arid regions, which are characterized by strong sunshine, high temperatures of up to $40{ }^{\circ} \mathrm{C}$ (Sousa et al., 2014), and scarce and irregular rains, which can compromise the quantity and quality of the water stored in sources (Abdelsattar, Hussein, Abd El-Ati, \& Saleem, 2020). Japanese quail is a bird that is adapted to arid and semi-arid regions, with a small size, earliness, productivity, which uses small spaces and little labor for production (Guimarães et al., 2014; Khalilipour, Maheri, \& Shaddel, 2019). In semi-arid regions, the available waters may have a high concentration of minerals, such as magnesium (Melo et al., 2017; Adimalla, 2019), which is an essential micronutrient in the diet of birds and participates in cell metabolism, bone development, cell energy metabolism, ribosomal integrity, and cell membrane (Shastak \& Rodehutscord, 2015). Quails are tolerant to magnesium-rich waters (Tao, Fry, \& Fox, 1983), as well as saline waters (Petrucci et al., 2017; Lima, Morais, \& Barreto,
2020). Magnesium levels between 14 and $125 \mathrm{mg} \mathrm{L}^{-1}$ can be added to the water with no harm to birds (Hevia \& Quiles, 1998). However, supplies above this limit may cause adverse effects, such as intestinal irritation, diarrhea, and reduced growth and egg production rates (Casey \& Meyer, 2001). Seo et al. (2010) and Kim, Paik, \& Kil (2013) cite increased weight and improved egg quality of laying hens supplemented with magnesium in the diet with ambient temperatures at $21^{\circ} \mathrm{C}$ and $22 \pm 3$ ${ }^{\circ} \mathrm{C}$, respectively. Different concentrations of salts in the water can cause changes in the weight of the birds and their organs (Lima et al., 2014; Khalilipour et al., 2019), constituting physiological adjustments. Age, sex, and nutrient content in the diet can increase metabolism (Loyau et al., 2015) and, consequently, change the weight of the organs, such as heart, liver and gizzards.

Birds are sensitive to thermal stress due to their high metabolic activity. Modern genotypes produce more body heat, and laying quails are tolerant to hot climates, but their thermal comfort zone is between 22 
and $26^{\circ} \mathrm{C}$ (El-Tarabany, 2016; Castro, Yanangi, Ferraz, \& Fassani, 2017; Silva et al., 2017), with relative humidity between 65 and $70 \%$. High temperatures can make it difficult to exploit and maximize quail production (Lima et al., 2014; Akdemir, Köseman, \& Şeker, 2019), and small environmental changes are perceived by birds (Castro et al., 2017; Santos, Gates, Tinôco, Zolnier, \& Baêta, 2017), causing an increase in water intake and a reduction in feed intake, which reduces egg production and quality (Vercese et al., 2012; El-Tarabany, 2016; Castro et al., 2017; Soares et al., 2019).

Therefore, the objective of this study was to evaluate increasing levels of magnesium in the water supplied to laying quails (Coturnix japonica), kept in climatic chambers under thermoneutral temperature and under thermal stress, on their performance and morphometry of their organs.

\section{Material and Methods}

All procedures used were approved by the Animal Use Ethics Committee of the Federal University of Campina Grande - UFCG (Protocol Number 089.2017). The experiment was carried out in two climatic chambers, dimensions of $3.07 \times 2.77 \times 2.6$ $\mathrm{m}$, in length, width and height, respectively (Figure 1), located at the Rural Construction and Ambience Laboratory at UFCG.

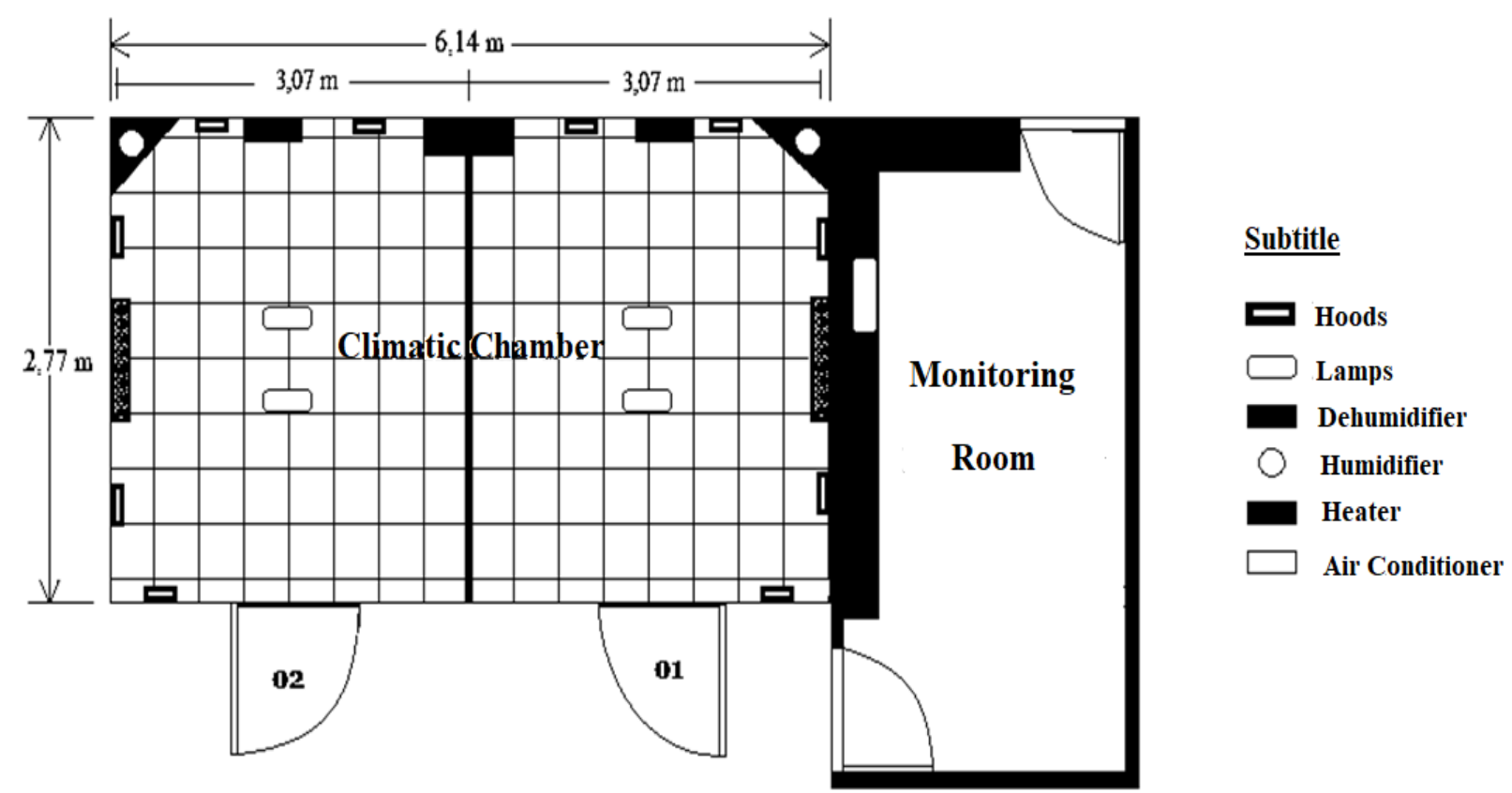

Figure 1. Internal layout of the climatic chambers and the monitoring room. 
For environmental control, the chambers were equipped with an electric resistance air heater, a hot/cold split air conditioner, with a power of 18,000 BTUs and an air humidifier, with a capacity of $4.5 \mathrm{~L}$ and a mist flow (average value) of $300 \mathrm{~mL} \mathrm{~h}^{-1}$. The relative humidity of the air was controlled by air humidifiers and measured by sensors. The wind speed was obtained through side fansand exhaust fans. The chambers had temperature and humidity sensors, and environmental data were collected and recorded every 15 min by sensors coupled to the data acquisition system, through a Full Gauge Controls ${ }^{\circledR}$ MT-530 PLUS controller, controlled via computer through SITRAD ${ }^{\circledR}$ (software for data acquisition, control, monitoring and visualization in climatic chambers).

Fluorescent lamps of 20W and 220V were used to light the chambers, and the daily light program adopted was of 17 hours of light and 7 hours of darkness. The relative humidity of the air in the chambers during the experimental period was $65.0 \pm 5.0 \%$ and the average wind speed was $2.0 \pm 0.5 \mathrm{~m} \mathrm{~s}^{-1}$.

In the pre-experimental period, 494 nine-week-old quails were used, housed in clusters of cages in the chambers, each cluster consisting of four floors, three cages per floor, made of galvanized wire, dimensions of $50 \times 33 \times 20 \mathrm{~cm}$ (width, depth, and height, respectively), submitted to the stocking rate of $206 \mathrm{~cm}^{2}$ bird $^{-1}$. The cages were equipped with zinc sheet trough feeders and individual nipple drinkers.

The birds went through an adaptation period of three weeks, in which the chambers were pro-grammed to keep the quails under temperature of thermal comfort $\left(24^{\circ} \mathrm{C}\right)$ during the day and under room temperature at night.
Egg production was counted and, at the end, the quails were weighed for homogeneous distribution in the experimental units, considering the body weight and the average laying rate of the birds. After the distribution, the chamber temperatures were adjusted to $24{ }^{\circ} \mathrm{C}$, within the thermal comfort zone, and $32{ }^{\circ} \mathrm{C}$, above the thermal comfort zone. These values were maintained for a period of 12 hours ( 7 am to $7 \mathrm{pm}$ ). The chamber doors were opened from 7:01 pm to 6:59 am at room temperature, simulating the conditions of the Brazilian semi-arid region.

For the experimental period, 384 14-week-old quails were selected and distributed in a completely randomized experimental design, in a $2 \times 4$ factorial scheme [two temperatures $\left(24\right.$ and $32^{\circ} \mathrm{C}$ ) $x$ four levels of magnesium in the water $(50,150,250$ and $\left.\left.350 \mathrm{mg} \mathrm{L}^{-1}\right)\right]$, totaling eight treatments, with six repetitions of eight birds each.

To obtain these four magnesium levels, magnesium chloride $\left(\mathrm{MgCl}_{2} \cdot 6 \mathrm{H}_{2} \mathrm{O}\right)$, A.R. with 203.3 molecular weight of salt, was added to mineral water with low salt content (1.45 $\mathrm{mg} \mathrm{L}^{-1} \mathrm{Mg}$ ) and correcting to obtain total treatment weight (Tn)

In the composition of the salt, as the magnesium chloride is hexahydrate, the weight of magnesium in the composition represented $12 \%$ of the total weight of the added salt. The remainder was composed of chloride ions (Table 1) and water molecules. The waters with magnesium concentrations were stored in 200-L buckets with lids and used daily in the drinkers according to the treatments. The water was prepared by weighing the proportion of $\mathrm{MgCl}_{2}$ salt for each 10 liters of water for each treatment, and the electrical conductivity level was checked 
at completion of each prepared dilution by using a digital conductivity meter (ITCD 1000 model - Instrutemp). Water analysis was carried out at the UFCG Irrigation and Salinity Laboratory (Table 1).

Table 1

Water already added with magnesium chloride $\left(\mathrm{MgCl}_{2}\right)$

\section{Variable}

50

7.70

737.50

4.00

50.00

92.68

0.78

173.70

42.70

0.07
Magnesium chloride ( $\left.\mathrm{mg} \mathrm{L}^{-1}\right)$

150

7.70

2.016 .00

4.80

150.00

97.06

0.78

492.05

42.09

0.07
250

7.70

3.219 .00

7.00

250.00

94.76

0.78

866.75

41.48

0.07
350

7.20

4.204.00

5.60

350.00

94.76

0.78

1.152 .00

43.31

Iron ( $\left.\mathrm{mg} \mathrm{L}^{-1}\right)$

During the experimental period, the birds were subjected to identical food management, consuming feed for laying quails based on corn and soybean meal. The nutritional composition of the ingredients used was obtained based on the tables by Rostagno et al. (2011), with water and feed being provided daily, manually and ad libitum. Leftovers and waste were weighed and discounted from the amount of feed weighed initially to calculate the feed and water intake of the birds.

At the beginning of the experiment the birds were $168 \pm 5 \mathrm{~g}$ (14 weeks of age) and at the end $175 \pm 5 \mathrm{~g}$ (24 weeks). Egg quality analysis was carried out every 21 days, with three evaluation periods, analyzing the following performance characteristics: feed intake (g/bird/day), water consumption ( $\mathrm{ml} /$ bird/day), egg production (\%), egg weight (g), egg mass ( $\mathrm{g} / \mathrm{bird} /$ day) and feed conversion ( $\mathrm{kg} / \mathrm{kg}$ and $\mathrm{kg} /$ dozen).

The average egg production was obtained by collecting the number of eggs daily, correcting for mortality, with the ratio of whole eggs produced expressed as a percentage, considering the average of birds of the period (\%/bird/day), corresponding to the production of marketable eggs. All eggs produced in each repetition were weighed during the last three days of each period to obtain the average weight, which was multiplied by the total number of eggs produced during the period to obtain the total egg mass. This mass was divided by the total number of birds per day, expressed in grams of egg/bird/day. The feed conversion per dozen eggs was determined by the total feed intake 
(kg) divided by the dozens of eggs produced (kg/dozen) and the conversion per egg mass, by the egg mass in kilograms $(\mathrm{kg} / \mathrm{kg})$.

To analyze the weight of the organs, 96 quails were slaughtered, two birds per repetition (48 in each environment). These quails were subjected to fasting of solids for twelve hours to empty the contents of the gastrointestinal tract, while receiving only water. After this period, they were stunned, slaughtered, plucked, eviscerated and subjected to organ separation: heart, liver and gizzard, which were weighed by using a $0.01 \mathrm{~g}$ precision digital scale. The heart and liver were removed and weighed. The gizzard was opened and the contents removed, then it was washed under running water, dried on paper towels and weighed.
The data were subjected to analysis of variance (ANOVA) and the averages were compared by Tukey's test at the level of $5 \%$ probability using PRO GLM. The effects of magnesium levels were estimated by PROC REG of SAS (2001).

\section{Results and Discussion}

There was no significant effect $(P>0.05)$ of the interaction between temperatures and water magnesium levels for performance variables. Magnesium influenced water consumption ( $P=0.0401)$ of the birds. At the highest temperature, there was a reduction $(P<0.05)$ in feed intake and feed conversion, with no significant differences $(P>0.05)$ in the other performance variables (Table 2).

\section{Table 2}

Performance averages of Japanese quails subjected to different levels of magnesium in water, at comfort temperature $\left(24^{\circ} \mathrm{C}\right)$ and heat stress temperature $\left(32^{\circ} \mathrm{C}\right)$

\begin{tabular}{|c|c|c|c|c|c|c|c|}
\hline \multicolumn{2}{|c|}{ Effect } & $\begin{array}{l}\text { Feed con- } \\
\text { sumption } \\
\text { (g/bird/day) }\end{array}$ & $\begin{array}{c}\text { Water } \\
\text { consump-tion } \\
\text { (mL/bird/day) }\end{array}$ & $\begin{array}{l}\text { Production } \\
\text { (\%) }\end{array}$ & $\begin{array}{l}\text { Egg } \\
\text { weight } \\
\text { (g) }\end{array}$ & $\begin{array}{c}\text { Egg } \\
\text { mass (g/ } \\
\text { bird/day) }\end{array}$ & $\begin{array}{c}\text { Feed } \\
\text { conver- } \\
\text { sion }(\mathrm{g} / \mathrm{g})\end{array}$ \\
\hline \multirow{4}{*}{$\begin{array}{l}\text { Magnesium } \\
\left(\mathrm{mg} \mathrm{L}^{-1}\right)\end{array}$} & 50 & 22.88 & $38.75 a$ & 73.10 & 11.70 & 8.58 & 0.38 \\
\hline & 150 & 22.67 & $36.43 b$ & 69.95 & 11.64 & 8.16 & 0.40 \\
\hline & 250 & 22.93 & $42.66 a$ & 71.56 & 11.72 & 8.38 & 0.39 \\
\hline & 350 & 23.38 & 38.70ab & 72.91 & 11.47 & 8.37 & 0.39 \\
\hline \multirow{2}{*}{$\begin{array}{l}\text { Temperature } \\
\left({ }^{\circ} \mathrm{C}\right)\end{array}$} & 24 & $23.98 a$ & 39.48 & 71.43 & 11.64 & 8.33 & $0.41 a$ \\
\hline & 32 & $21.96 b$ & 38.79 & 72.34 & 11.62 & 8.41 & $0.36 b$ \\
\hline \multirow[t]{2}{*}{ MSE } & 1.63 & 5.14 & 9.27 & 0.42 & 1.14 & 0.05 & \\
\hline & & & P-value & & & & \\
\hline \multicolumn{2}{|c|}{ Temperature } & 0,0001 & 0.6475 & 0.7365 & 0.8656 & 0.7919 & 0.0076 \\
\hline \multicolumn{2}{|c|}{ Magnesium } & 0.7502 & 0.0401 & 0.8278 & 0.4629 & 0.8489 & 0.7626 \\
\hline \multicolumn{2}{|c|}{ Temperature $\mathrm{x}$ Magnesium } & 0.9410 & 0.8553 & 0.5638 & 0.8243 & 0.5874 & 0.4095 \\
\hline \multicolumn{8}{|c|}{ P-value } \\
\hline \multicolumn{2}{|c|}{ Linear } & 0.4657 & 0.3802 & 0.9304 & 0.2394 & 0.7750 & 0.7859 \\
\hline \multicolumn{2}{|c|}{ Quadratic } & 0.5397 & 0.5991 & 0.3909 & 0.4197 & 0.5262 & 0.5084 \\
\hline
\end{tabular}

Means followed by different letters differ statistically by Tukey's test at 5\% probability; MSE = mean standard error. 
Quails are tolerant to high levels of minerals in water and feed (Lima et al., 2015; Scottá et al., 2017; Lima et al., 2020), and the levels of $\mathrm{Mg}$ ingested did not influence feed intake, demonstrating the tolerance of the birds to magnesium-rich waters (Tao et al., 1983). Bird organisms do not have adaptations to chronic low or high ingestions of $\mathrm{Mg}$; excretion in urine is the main regulator of $\mathrm{Mg}$ body homeostasis (Shastak \& Rodehutscord, 2015).

Poultry kept under thermal stress decreased feed intake by $8.42 \%(2.02 \mathrm{~g})$ and this is due to the need to reduce body heat (Tao et al., 1983; El-Tarabany, 2016; Santos et al., 2019). Quails may have difficulty exchanging heat with the environment due to the absence of sweat glands and because their bodies are covered with feathers. The reduction in feed intake is an adjustment in energy ingestion and reduces the production of body heat (Vercese et al., 2012; Castro et al., 2017), but it may cause an energy deficit by reducing the availability of nutrients for production, since heat dissipation occurs with energy expenditure (Loyau et al., 2015). Tao et al. (1983) cite that weight gain and feed intake of Japanese quails kept under cyclic temperatures of thermal stress $\left(34^{\circ} \mathrm{C}\right)$ and mild temperatures were higher in birds supplemented with magnesium oxide and Mg-protein.

Water consumption was reduced with the level of $\mathrm{Mg}$ in the water at $150 \mathrm{mg} \mathrm{L}-1$, but similar to that obtained with the level of 350 mg L-1. To avoid any compromise in poultry production, the recommendation is that the water should not have more than $1000 \mathrm{mg}$ L-1 (National Research Council [NRC], 1994). An average water consumption of $1.7 \mathrm{~L}$ for each kilogram of feed consumed and higher
Mg concentrations can stimulate urinary frequency and cause diarrhea, facts that stimulate water replacement via consumption; however, up to the level of $350 \mathrm{mg} \mathrm{L}-1$ this stimulus was not externalized. The increase of salt in water can elevate the sensation of thirst due to the increase in plasma osmolality and the neurohormonal mechanisms that stimulate the center of thirst.

Under thermal stress, the birds' demand for water can be high to meet nonevaporative caloric loss (Santos et al., 2019). However, water consumption was not affected by the increase in ambient temperature. These results may be due to the management in which quails were subjected to cyclic heat stress for 12 hours.

The production performance of quails may be influenced by genetic variability in the breeding environment, poultry management, feed, and the water offered (Ribeiro et al., 2017; Akdemir et al., 2019), although increasing levels of magnesium did not interfere in the performance of the birds, which stayed within the standard for the species (Vercese et al., 2012; Guimarães et al., 2014). High concentrations of magnesium in the water can result in a bitter taste and low palatability, which can limit consumption. However, when supplying water with up to $350 \mathrm{mg} \mathrm{L-1}$ of magnesium to quails, this was not found. Kudo, Shiraishi, Nishimura, Bungo, \& Tabata (2010) mention that sensitivity to bitter taste is related to the number of gustatory papillae, which in chickens is lower than in mammals. This makes them less sensitive to palatability.

The weight of a quail egg can vary between 10 and $13 \mathrm{~g}$. Even under thermal stress, quails are able to maintain production and quality of the products (Guimarães et al., 
2014; Rodrigues, Furtado, Costa, Nascimento, \& Cardoso, 2016; Petrucci et al., 2017). However, these variables can be reduced in quails kept under thermal stress (El-Tarabany, 2016; Santos et al., 2017; Silva et al., 2017; Akdemir et al., 2019), due to the reduction in food intake, reduced digestibility of diet components, and mobilization and use of body reserves to maintain body temperature. Although quails kept at a temperature of $24^{\circ} \mathrm{C}$ consume more feed, the percentages of egg laying, weight and mass were similar to those of quails kept at stress temperature.
The variables of performance and egg quality of birds can be reduced by the oxidative stress that results from high environmental temperatures (Akdemir et al., 2019; Soares et al., 2019), and there was a reduction in feed conversion of the birds at the stress temperature, a fact that may be correlated with lower feed intake.

There was no interaction between temperatures and magnesium levels in the water for organ morphometry, and the different levels of magnesium in the water and temperatures did not affect $(P<0.05)$ the weight and percentage of the quail heart, liver, and gizzard (Table 3).

\section{Table 2}

Averages of absolute and relative weight of the quail's organs submitted to different levels of magnesium in the water, at comfort temperature $\left(24^{\circ} \mathrm{C}\right)$ and thermal stress $\left(32^{\circ} \mathrm{C}\right)$

\begin{tabular}{|c|c|c|c|c|c|c|c|c|}
\hline \multirow{2}{*}{\multicolumn{2}{|c|}{ Effect }} & \multirow{2}{*}{$\begin{array}{c}\text { Live weight } \\
\text { (g) }\end{array}$} & \multicolumn{2}{|c|}{ Heart } & \multicolumn{2}{|c|}{ Liver } & \multicolumn{2}{|c|}{ Gizzard } \\
\hline & & & (g) & (\%) & (g) & (\%) & (g) & (\%) \\
\hline \multirow{4}{*}{$\begin{array}{l}\text { Magnesium } \\
\left(\mathrm{mg} \mathrm{L}^{-1}\right)\end{array}$} & 50 & 167.02 & 1.50 & 0.90 & 6.00 & 3.64 & 3.33 & 2.03 \\
\hline & 150 & 163.83 & 1.57 & 0.97 & 5.91 & 3.62 & 4.19 & 2.60 \\
\hline & 250 & 165.48 & 1.49 & 0.91 & 5.74 & 3.49 & 3.04 & 1.84 \\
\hline & 350 & 168.63 & 1.60 & 0.95 & 7.86 & 4.66 & 3.17 & 1.88 \\
\hline \multirow{2}{*}{$\begin{array}{l}\text { Temperature } \\
\left({ }^{\circ} \mathrm{C}\right)\end{array}$} & 24 & 166.66 & 1.58 & 0.96 & 6.20 & 3.75 & 3.27 & 1.98 \\
\hline & 32 & 165.81 & 1.50 & 0.90 & 6.56 & 3.96 & 3.59 & 2.20 \\
\hline SEM & & 15.95 & 0.25 & 0.17 & 4.07 & 2.42 & 2.02 & 1.31 \\
\hline \multicolumn{9}{|l|}{ P-value } \\
\hline \multicolumn{2}{|c|}{ Temperature } & 0.8551 & 0.2395 & 0.2681 & 0.7573 & 0.7708 & 0.5834 & 0.5747 \\
\hline \multicolumn{2}{|c|}{ Magnesium } & 0.8958 & 0.6679 & 0.7073 & 0.5412 & 0.6187 & 0.5062 & 0.4734 \\
\hline \multicolumn{2}{|c|}{ Temperature $\mathrm{x}$ Magnesium } & 0.9165 & 0.7704 & 0.7360 & 0.2524 & 0.2713 & 0.5464 & 0.5259 \\
\hline \multicolumn{9}{|l|}{ P-value } \\
\hline \multicolumn{2}{|c|}{ Linear } & 0.7406 & 0.4565 & 0.6886 & 0.3011 & 0.3506 & 0.5254 & 0.4740 \\
\hline \multicolumn{2}{|c|}{ Quadratic } & 0.4719 & 0.8238 & 0.7572 & 0.3459 & 0.3942 & 0.5349 & 0.4838 \\
\hline
\end{tabular}

Means followed by different letters differ statistically by Tukey's test at 5\% probability; MSE = mean standard error. 
The birds' weight was $168 \pm 5 \mathrm{~g}$ at the beginning of the experiment, and $175 \pm 5 \mathrm{~g}$ at the end, an average of $171.5 \pm 5 \mathrm{~g}$. Therefore, even consuming water with high levels of magnesium and kept under thermal stress, the birds managed to raise their weight. Part of the percentage of the magnesium ingested is fixed in the bones, and another percentage goes into the composition of the molecular mass and blood (Shastak \& Rodehutscord, 2015); therefore, the concentration of magnesium in the water can help in the maintenance or gain of weight in quails under thermal stress. Harland, Fox, \& Fry (1976) cite that $300 \mathrm{mg} \mathrm{L}^{-1}$ of magnesium was considered adequate to meet the requirements of Japanese quails of up to 14 days of age, and higher levels caused growth retardation and high mortality.

Weight of quail organs can vary according to age, weight, sex, ambient temperature and types of food and water (Vasconcelos, Pires, Lima, \& Ballotin, 2014). The magnesium levels of the water did not interfere with the weight and percentage of the heart, an average of $1.54 \mathrm{~g}$, similar to that reported by Rodrigues et al. (2016) in laying quails and by Camelo et al. (2015), in studies with guava bran in the diet of European quails.

The weights and percentages of the liver were similar between treatments. The birds' tolerance to $\mathrm{Mg}$ must be less than 125 $\mathrm{mg} \mathrm{L}^{-1}$ (Hevia \& Quiles, 1998), and this mineral participates in the metabolism of cellular energy and modulates the activities of various membrane transport systems with liver action. Higher levels of Mg can cause physiological disorders in the digestive organs, but the consumption of water with levels of up to 350 $\mathrm{mg} \mathrm{L}^{-1}$ did not promote physiological changes, demonstrating tolerance of the quails to waters with higher magnesium contents. Lima et al. (2014) cite that increasing levels of water electrolyte balance $(0,30,60,90$, $120 \mathrm{mEq} / \mathrm{L}$ ) reduced the relative weight of the heart and liver. Rodrigues et al. (2016) mention that quails raised in cyclic temperatures of 12 hours each of heat and thermoneutral temperature did not affect the weight of the liver. There may be a reduction in the weight of the organs due to the reduction in feed intake (Silva et al., 2017), associated with lower maintenance requirement, reduction in mass, and activity of internal organs (Salabi, Fayazi, Nazari, Boujarpoor, \& Salari, 2011).

The weight of the gizzard is related to the feed intake, which was higher at the thermoneutral temperature, but not enough to affect this weight in comparison to the stress temperature. Ensuring ideal conditions for the production and action of these enzymes is essential in the supply and absorption of nutrients that will be destined for metabolic processes related to the growth and maturation of the organs of these animals (Yamauchi \& Tarachai, 2000).

\section{Conclusions}

Japanese quails in the production phase can consume water with magnesium levels of up to $350 \mathrm{mg} \mathrm{L}^{-1}$, and be maintained at temperatures of up to $32^{\circ} \mathrm{C}$ for up to 12 hours a day, without affecting productive performance and organ morphometry.

\section{References}

Abdelsattar, M. M., Hussein, A. M. A., Abd ElAti, M. N. \& Saleem, A. M. (2020). Impacts of saline water stress on livestock production: a review. International Journal of Agricultural Science, 2(1), 1-12. doi: 10.21608/svuijas.2020.67635 
Adimalla, N. (2019). Groundwater Quality for drinking and irrigation purposes and potential health risks assessment: a case study from semi arid region of South India. Exposure and Health, 11, 109-123. doi: 10.1007/s12403-018-0288-8

Akdemir, F., Köseman, A., \& Şeker, I. (2019). Alchemilla vulgaris effects on egg production and quality expressed by heat stressed quail during the late laying period. South African Journal of Animal Science, 49(5), 857-868. doi: 10.4314/ sajas.v49i5.8

Camelo, L. C. L., Lana, G. R. Q., Santos, M. J. B., Camelo, Y. A. R. P., Marinho, A. L., \& Rabello, C. B. (2015). Inclusion of guava wastes in the diet of European quails. Ciência Animal Brasileira, 16(3), 343-349. doi: 10.1590/1089-6891v16i324342

Casey, N. H., \& Meyer, J. A. (2001). An extension to and further refinement of a water quality guideline index system for livestock watering. Poultry production systems and water quality for ostrich production (vol. 2). Pretoria: Report to the Water Research Commission. WRC Report.

Castro, J. O., Yanangi, T., Jr., Ferraz, P. F. P., \& Fassani, E.J.(2017). Japaneselaying quails behavior under different temperatures. Energia na Agricultura, 32(2), 141-147. doi: 10.17224/EnergAgric.2017v32n2p1 41-147

El-Tarabany, M. S. (2016). Impact of temperature-humidity index on egg-laying characteristics and related stress and immunity parameters of japanese quails. International Journal of Biometeorology, 60(7), 957-964. doi: 10.1007/s00484-015 $-1088-5$
Guimarães, M. C. C., Furtado, D. A., Nascimento, J. W. B., Tota, L. C. A., Silva, C. M., \& Lopes, K. B. P. (2014). Effect of season on production performance of quail in the semiarid region of Paraiba state, Brazil. Revista Brasileira de Engenharia Agrícola e Ambiental, 18(2), 231-237. doi: 10.1590/ S1415-43662014 000200015

Harland, B. F., Fox, M. R., \& Fry, B. E., Jr. (1976). Magnesium deficiency, requirement and toxicity in the young japanese quail. Poultry Science, 55(1), 359-364. doi: 10.3382/ps.0550359

Hevia, M. L., \& Quiles, A. (1998). La calidad del agua en avicultura. Selecciones Avícolas, 40, 403-406.

Khalilipour, G., Maheri, N. S., \& Shaddel, A. T. (2019). Effects of saline drinking water on growth performance and mortality rate of japanese quails (Coturnix coturnix Japonica). Journal Agricultural National, 22(6), 942-947. doi: 10.18016/ ksutarimdoga.vi.553366

Kim, C. H., Paik, I. K., \& Kil, D. Y. (2013). Effects of increasing supplementation of magnesium in diets on productive performance and eggshell quality of aged laying hens. Biological Trace Element Research, 151(1), 38-42. doi: 10.1007/ s12011-012-9537-z

Kudo, K., Shiraishi, J., Nishimura, S., Bungo, T., \& Tabata, S. (2010). The number of taste buds is related to bitter taste sensitivity in layer and broiler chickens. Animal Science Journal, 81(2), 240-244. doi: 10.111 1/j.1740-0929.2009.00729.x

Lima, H. J. D., Barreto, S. L. T., Paula, E., Dutra, D. R., Costa, S. L., \& Abjaude, W. S. (2015). Níveis de sódio na ração de 
codornas japonesas em postura. Revista Brasileira de Saúde e Produção Animal, 16(1), 73-81. doi: 10.1590/S1519-994 02015000100009

Lima, H. J. D., Morais, M. V. M., \& Barreto, S. L. T. (2020). Japanese laying quail. Research, Society and Development, 9(6), 1-4. doi: 10.33448/rsd-v9i6.2486

Lima, R. B., Silva, J. H. V., Givisiez, P. E. N., Martins, T. D. D., Saraiva, E. P., Costa, F. G. P. \& Macari, M. (2014). Influence of environmental temperature and electrolyte balance on the performance of quails Coturnix coturnix coturnix. Brazilian Journal of Poultry Science, 16(3), 249256. doi: 10.1590/1516-635×1603249256

Loyau, T., Bedrani, L., Berri, C., MetayerCoustard, S., Praud, C., Coustham, V.,... Collin, A. (2015). Cyclic variations in incubation conditions induce adaptive responses to later heat exposure in chickens: a review. Animal, 9(1), 76-85. doi: 10.1017/S1751731114001931

Melo, D. F., Furtado, D. A., Dantas, J., Neto, Matos, J. J. L., Leite, P. G., \& Santos, R. T. (2017). Physiochemical quality of waters of different sources used for animal consumption in the semiarid Brazilian. Revista Espacios, 38(38), 28-35.

National Research Council (1994). Nutrient requirements of domestic animals. Nutrient requirements of poultry (9nd ed.). Washington, DC: Natl. Acad. Sci.

Petrucci, F. B., Bonaparte, T. P., Scottá, B. A., Vargas, J. G., Jr., Vieira, D. V. G., \& Marin, J. F. V. (2017). Sodium levels in food of Japanese quail in the laying phase. Revista Verde de Agroecologia e
Desenvolvimento Sustentável, 12(2), 338342. doi: 10.18378/rvads.v12i2.4391

Ribeiro, J. C., Silva, L. P., Soares, A. C. C., Caetano, G. C., Leite, C. D. S., Bonafé, C. M., Torres, R. A. (2017). Genetic parameters for egg production in meat quails through partial periods. Ciência Rural, 47(4), 1-7. doi: 10.1590/0103-8478cr20160374

Rodrigues, L. R., Furtado, D. A., Costa, F. G. P., Nascimento, J.W.B., \& Cardoso, E. A. (2016). Thermal comfort index, physiological variables and performance of quails fed with protein reduction. Revista Brasileira de Engenharia Agrícola e Ambiental, 20(4), 378-384. doi: 10.1590/1807-1929/ agriambi.v20n4 p378-384

Rostagno, H. S., Albino, L. F. T., Donzele, J. L., Gomes, P. C., Oliveira, R. F., Lopes, D. C.,... Euclides, R. F. (2011). Brazilian tables for poultry and swine - composition of feedstuffs and nutritional requirements (3nd ed.). Viçosa MG: Editora da UFV.

Salabi, F, Fayazi, J., Nazari, M., Boujarpoor, M., \& Salari, S. (2011). Effects of different levels of zinc $n$ the performance and carcass characteristics of broiler reared under heat stress condition. Journal of Animal and Veterinary Advances, 10(10), 13321335. doi: 10.3923/javaa.2011.1332.1335

Santos, T.C., Gates, R.S., Tinôco, I. F.F.,Zolnier, S., \& Baêta, F. C. (2017). Behavior of Japanese quail in different air velocities and air temperatures. Pesquisa Agropecuária Brasileira, 52(5), 344-354. doi: 10. 1590/ s0100-204x2017000500008

Santos, T. C., Gates, R. S., Tinôco, I. F. F., Zolnier, S., \& Baêta, F. C. (2019). Productive performance and surface temperatures of Japanese quail exposed to different 
environment conditions at start of lay. Poultry Science, 98(7), 2830-2839. doi: 10.3382/ps/pez068

Scottá, B. A., Bonaparte, T. P., Vargas, J. G., Jr., Petrucci, F. B., Vieira, V. G. D., Marin, J. F. V.,... Soares, R. T. R. (2017). Sodium and potassium at different levels of crude protein for laying quais. Revista Agrarian, 10(35), 76-83. doi: 10.30612/agrarian. v10i35.4437

Seo, Y. M., Shin, K. S., Rhee, A. R., Chi, Y. S., Han, J., \& Paik, I. K. (2010). Effects of dietary fe-soy proteinate and mgo on egg production and quality of eggshell in laying hens. Asian Australasian Journal of Animal Science, 23(8), 1043-1048. doi: 10.5713/ajas.2010.10076

Shastak, Y., \& Rodehutscord, M. (2015). A review of the role of magnesium in poultry nutrition. World's Poultry Science Journal, 71(1), 125-138. doi: 10.1017/ S0043933915000112

Silva, R. C., Nascimento, J. W. B., Rodrigues, L. R., Leite, P. G., Galvão Sobrinho, T., \& Furtado, D. A. (2017). Quality of quail eggs confined in thermoneutral environment and heat stress. Journal of Animal Behaviour and Biometeorology, 5(4), 139-143. doi: 10.31893/2318-1265jabb. v5n4p139-143

Soares, K. O., Saraiva, E. P., Santos, J. D. C., Amorim, R. G., Costa, J. L. G., Veríssimo, T. S.,... Santos, S. G. C. S. (2019). Effect of ambient temperature on the production parameters and egg quality of Japanese quail (Cortunix japonica). Biological Rhythm Research, 52(7), 1130-1137. doi: 10.1080/09291016.2019. 1619128
Sousa, M. S., Tinôco, I de F. F., Amaral, A. G., Inoue, K. R. A., Barreto, S. L., Savastano, Jr., H. I. Souza, C. F. Paula, M. O. (2014). Thermal Comfort Zones for Starter Meat-Type Quails. Brazilian Journal of Poultry Science, 16(3), 265-272. doi. org/10.1590/1516-635×1603265-272

Statistical Analyses System (2001). Statistical analysis system user's guide. Version 9.1. Cary: Statistical Analyses System Institute.

Tao, S. H., Fry, B. E., Jr., \& Fox, M. R. (1983). Magnesium stores and anemia in young Japanese quail. Journal Nutrition, 113(6), 1195-1203. doi: 10.1093/jn/113.6.1195

Yamauchi, K., Tarachai, P. (2000). Changes in intestinal villi, cell area and intracellular autophagic vacuoles related to intestinal function in chickens. British Poultry Science, 41(4), 416-423

Vasconcelos, R. C., Pires, A. V., Lima, H. D., \& Ballotin, L. M. V. (2014). Meat quails carcass characteristics fed with different protein and energy levels. Revista Brasileira de Saúde e Produção Animal, 15(4), 10171026.

Vercese, F., Garcia, E. A., Sartori, J. R., Silva, A. P., Faitarone, A. B. G. I., Berto, D. A. I.,... Pelícia, K. (2012). Performance and egg quality of Japanese quails submitted to cyclic heat stress. Brazilian Journal of Poultry Science, 14(1), 37-41. doi: 10.15 90/S1516-635X2012000100007 